\title{
A Eclesiologia Latino-americana como acolhimento criativo do Vaticano II Um caminho para uma nova recepção da herança conciliar
}

Orientador: Ana Maria de A. L. Tepedino

Mestrando: Flavio Luis Alves

Área de Concentração: Teologia Sistemático-Pastoral

Linha de Pesquisa: Religião e Modernidade

A presente dissertação intitulada: A Eclesiologia Latino-americana como acolhimento criativo do Vaticano II: Um caminho para uma nova recepção da herança conciliar desenvolveu-se estimulada pela reflexão que se vive hoje diante a uma mudança de época que demanda, por parte da Igreja, novas respostas aos desafios que se apresentam à evangelização na cultura atual. Parte-se do Concílio Vaticano II, onde a Igreja sente-se compelida diante do mundo a tomar decisões e dar um novo rumo à sua missão de evangelizar, promovendo assim uma renovação e mudança que possibilita uma nova consciência eclesial, que, por sua vez, é reconhecida e valorizada nos Documentos das Conferências Gerais do Episcopado Latino-americano. Esta nova concepção de Igreja adquire forte vitalidade no pós-Concílio na América Latina. A Igreja latino-americana, atenta aos sinais dos tempos, procura compreender e atualizar sua missão assumindo a realidade e a partir dela testemunha o Evangelho. As consequências eclesiológicas desta tradição latino-americana, possibilitada pelo Vaticano II, iniciada com a Conferência de Medellín e intensificada mais recentemente com a Conferência de Aparecida se apresentam como contribuições atuais para toda a Igreja e situam-se na direção de uma nova recepção da herança conciliar.

Palavras-chave: Eclesiologia Latino-Americana; Vaticano II; América Latina. 